\title{
Verification of Prediction Models in Conditions of Slovak Family Businesses operating in the Global Environment
}

\author{
Maria Kmety Bartekova ${ }^{1, *}$, Maria Truchlikova ${ }^{1}$, and Helena Majduchova ${ }^{1}$ \\ ${ }^{1}$ University of Economics in Bratislava, Faculty of Business Management, Dolnozemska cesta 1, \\ 85235 Bratislava, Slovakia
}

\begin{abstract}
Research background: Every business today is facing the greatest challenge in generations, as the pandemic forces owners to drastically rethink business models, supply chains and working practices. Familyowned businesses' long-term perspective, entrepreneurial spirit, agility and guiding sense of purpose, together with the resilience of their leadership teams make them especially well prepared to fight a such crisis, especially as their multi-generation perspective allows them to meet their customers' changing circumstances through economic cycles. The covid-19 crisis has produced some great examples of family businesses displaying their experience as innovators to support their governments and communities in need.

Purpose of the article: The aim of the paper is to verify and analyse the prediction credit models applied on the Slovak family businesses belonging to the Creative Industries and operating in the global environment.

Methods: In order to achieve the aim, namely the verification of existing 3 prediction models, universal methods were used, such as the analysis of available theoretical knowledge obtained by studying the literature and the subsequent synthesis of the acquired knowledge, the comparison of the issue addressed on the basis of the criteria set by the Commercial Code and the results of the observed prediction models, the methods of induction, deduction, description and excerpting.

Findings \& Value added: The essence of the analysis is the comparison of the results achieved using three prediction credit models with the prosperity criteria that considers the current valid legislation and the economic and financial aspects in order to verify the Slovak prediction models designed for the family businesses.
\end{abstract}

Keywords: Creative industries; Family-owned business, Prediction Models

JEL Classification: $F 65 ; Z 10 ; Z 18$

\footnotetext{
* Corresponding author: maya.bartekova@gmail.com
} 


\section{Introduction}

Family businesses are an important part of the economies of emerging and developed countries alike. Globally, they represent a socially significant phenomenon and contribute significantly to the creation of GDP (Prasetyo, 2016; Motylska-Kuzma, 2017). They operate in all commercial industries, take various legal forms and organizational structures, and have a range of different sizes - from micro, small and medium-sized enterprises to large, multinational, global corporations traded on exchanges (Cerdan and Hernandez, 2013; Wiener-Fererhofer, 2017). Absent timely and constructive responses to global shifts, many family businesses likely face decline or failure (Etemad, 2004; Fernandez and Nieto, 2005). In fact, a recent study by McKinsey and Company that applies to firms in developing as well as developed countries is quite blunt in the red flag it raises (Iwatani et al., 2011). The study concludes that, in light of emerging economic and demographic trends suggesting minimal growth in home markets, survival for many companies will likely depend on their ability to substantially increase revenues and profits from overseas ventures. Facing survival or demise undoubtedly creates urgency for family businesses to consider, or perhaps reconsider, entering the global marketplace (Etemad, 2021). Thus, going global may no longer be optional.

Families have done business for the majority of recorded history family businesses with a long tradition worldwide. And yet research into the specific characteristics of family businesses is a relatively new scientific discipline. In general, they are perceived as a fundamental driving force of global economic growth, prosperity, and stability of nations ().

According to Weclawski (2017), most small and medium-sized family businesses struggle with their preferences for equity or debt financing for investment in growth, innovation, and expansion. The scope of the need for financing, including external sources, depends on the family business's life cycle, the number of members in the family employed in the company, and the specific plans for its development. And yet, founders display an aversion to financing based on debt financing; in the case of a financial investor's entry, they are concerned about the loss of control over the business.

According to Csákné and Karmazin (2016), a review of family businesses' financial characteristics can lead to a duality of family and commercial dimensions. This duality is reflected in the financial decisions on the use of equity and debt financing, which reflects the business's financial needs and the financial needs or means of the family. Unique goals, governance, and financial resources of family businesses are not only the primary source of their heterogeneity, but the ratio of equity to debt financing is a key factor for the continuation of the family succession, development, and expansion of the business, as well as its financial settlement (Chrisman et al., 2013).

A full understanding of family business requires multi-faceted knowledge of economic, commercial, financial, organizational, psychological, entrepreneurial, managerial, and strategic areas (Ferramosca and Ghio, 2018; Valaskova et al., 2020).

\section{Methods and methodology}

The aim of the paper is to verify and analyse the prediction credit models applied on the Slovak family businesses belonging to the Creative Industries and operating in the global environment.

Tracking the development of financial ratios can greatly help a family business to better assess its current state and predict the state of its future finances. The application of modern methods of financial analysis in examining the management of a family business has given us a new perspective on the financial side of such an enterprise. The first part of the financial analysis was devoted to the development of costs, revenues and the result of the selected 
family business for a five-year period (2015-2019). We used the method of simple chain indices to monitor the development of costs and revenues.

Kiselakova, Soltes and Soltesova (2015) in the context of the issue of measuring the financial performance of enterprises provide the following breakdown of economic methods and models into two basic groups:

1. Standard models based on accounting profit, which can be further subdivided into standard ex-post financial analysis models - these are mainly the analysis of basic ratios through which basic financial information can be obtained about a company's financial position; standard models of ex ante financial analysis - it is mainly the analysis of predictive and credit models, which can predict the future financial situation of the analysed business unit.

2. Modern models based on economic profit, which take into account economic costs in addition to accounting costs and market indicators that reflect the market value of the business.

One of the most important steps a business should take is to prevent financial distress by forecasting the financial situation, where it is advisable to use ex ante predictive financial analysis that forecasts its future development and can predict financial distress based on the use of creditworthiness and bankruptcy models so that the business does not find itself in financial distress in the future (Valaskova \& Durana, 2020).

The Creditworthy model is a specific credit rating model for assessing the performance of a company. The model represents a portfolio in which the position of the rated companies is located at the intersection of the values plotted on the $\mathrm{x}$-axis and the $\mathrm{y}$-axis. The $\mathrm{x}$-axis is plotted against the future success value of the firm - family business, which is obtained from the calculated and point-transformed values of the firm's predictive models. The second ex ante model assessed in the paper is the Quick Test and the Douchy II model. We plot the scores of selected financial performance indicators on the $y$-axis. We convert the indicators into points using transformation tables. The portfolio is composed of performance fields, which are labelled as follows: unsatisfactory, doubtful, substandard, follow and excellent.

The analysis of the financial health of the selected family businesses operating in the global environment for the period 2015 - 2019 was carried out using the method of ex post and ex ante financial analysis. All calculations, graphs, tables and statistical methods used in the paper were processed in MS Excel. The basis for the assessment of the financial position of the selected company were the financial statements for the years 2015-2019, which we obtained from the publicly available register of financial statements and the Finstat database.

\section{Results and Discussion}

Predictive models contain a combination of indicators, including their weights, suitable for assessing the performance and credibility of a business. Determining the prosperity of a firm, which is the main objective of our paper, is the task of credit models that diagnose the financial health of a family business and determine whether to classify it as prosperous or non-prosperous. Taking into account the conditions of the national economy, its legislation, the action of financial instruments, but also the external context, the models can indicate the risks, weaknesses and strengths of the financial health of the family businesses.

In assessing the financial performance of the analysed family business operating in the global environment, 10 representative indicators were selected for each group of ratios, excluding market value. The assessment of success was carried out by scoring the selected 3 models. Based on the scoring tables, each selected metric was assigned a score ranging from 0 - 8 and $1-20$, respectively. The scores were then added up separately for each year under review and plotted on the $\mathrm{x}$ and $\mathrm{y}$ axis. The resulting portfolio for assessing the family businesses' performance in a particular year is shown in Figure 1. 


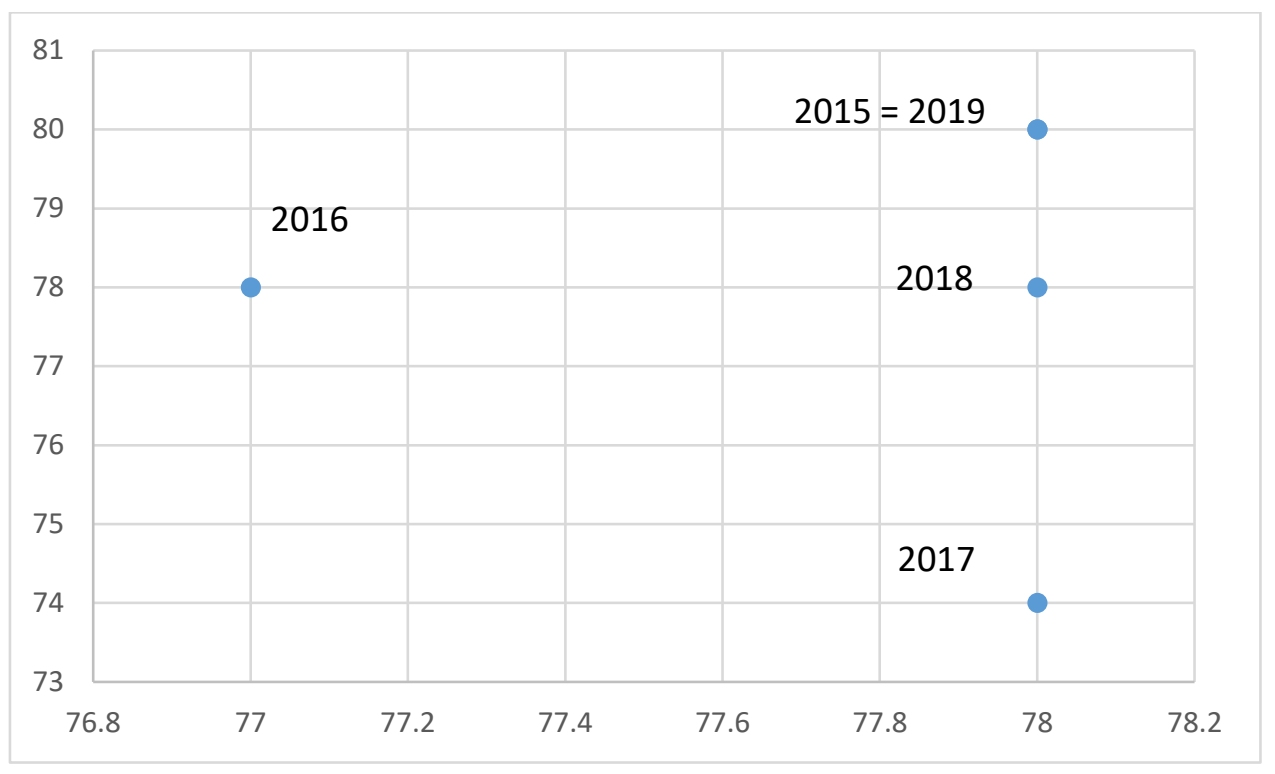

Figure 1. Results of the Creditworthy model

Source: author's calculations

The blue shading of the results highlights the differences we found when calculating the Rudolf Douchy II Balance Sheet Analysis and the Kralick Quicktest. Table 1 clearly shows that we arrived at different results, except for 2017 and 2019, in all years of the period under study.

Table 1. Results of the rating models - Quicktest and Douchy II model

\begin{tabular}{|c|c|c|c|c|c|}
\hline Model & $\mathbf{2 0 1 5}$ & $\mathbf{2 0 1 6}$ & $\mathbf{2 0 1 7}$ & $\mathbf{2 0 1 8}$ & $\mathbf{2 0 1 9}$ \\
\hline $\begin{array}{c}\text { Douchy } \\
\text { II }\end{array}$ & $\begin{array}{c}\text { Creditworthin } \\
\text { ess }\end{array}$ & $\begin{array}{c}\text { Financial } \\
\text { problems }\end{array}$ & $\begin{array}{c}\text { Grey } \\
\text { zone }\end{array}$ & $\begin{array}{c}\text { Creditworthin } \\
\text { ess }\end{array}$ & $\begin{array}{c}\text { Creditworthin } \\
\text { ess }\end{array}$ \\
\hline $\begin{array}{c}\text { Quickte } \\
\text { st }\end{array}$ & Grey zone & Grey zone & $\begin{array}{c}\text { Grey } \\
\text { zone }\end{array}$ & Grey zone & Grey zone \\
\hline
\end{tabular}

Source: author's calculations

In 2015, Rudolf Douchy II's Balance Sheet Analysis rated the organization as creditworthy (1.94), but the value of the Kralick Quicktest (2.4) was in the grey zone, which can be called neutral because it is not possible to clearly determine the situation of the family businesses. The following year (2016) was evaluated by the Balance Sheet Analysis of Rudolf Douchy II (- 0.57) as a year of problems in management, which was the result of the negative economic result of the selected family businesses. The Kralick Quicktest score (2.35) was again in the grey zone. The year 2017, in which the monitored family businesses achieved the highest positive economic result for the whole monitored period, was considered by the Balance Sheet Analysis of Rudolf Doucha II as the best - the achieved value was 9.47. In the case of the Kralick Quicktest, the score value (3.00) touched the threshold value separating the grey zone from the band of prosperity. In 2018, according to Rudolf Doucha II's Balance Sheet Analysis, the performance remained in the prosperity range (2.66). On the contrary, the value of Kralick's Quicktest (2.25) was also in the grey zone in this year. The last year monitored was 2019. In this year, the family businesses recorded the highest economic result, which was significantly reflected in the value of the indicators of the Rudolf Douchy II Balance Sheet Analysis. 


\section{Conclusions}

Methods for forecasting the financial position of a family business must enable the family enterprise to be classified with reasonable reliability as either a going concern or a non-going concern. However, this requires that the overall financial and economic performance of the family business be accurately expressed, which is the task of forecasting models. Different methods are used to quantify the synthetic discriminant and summarise the selected indicators.

In summary, we can conclude that the Creditworthy model is of undisputed importance for the evaluation of the performance of the family business, as it can provide a comprehensive and complete picture of the state and development of the financial situation. A family business can quantify the model quite easily and construct and also suitably adapt to your own criteria and requirements. The above reasons therefore only confirm the suitability of using this model in management practice.

\section{Acknowledgements}

This paper is the output of the scientific grant VEGA n. 1/0340/19 "The Entrepreneurial Dimension of Creative industries in the Context of Innovation and Smart Growth" (50\%) and the internal grant project of the University of Economics in Bratislava (Faculty of Business Management) no. I-21-109-00 called "Research of Family businesses in the context of sustainable development" (50\%).

\section{References}

1. Cerdan, A. L. M., \& Hernandez, A. J. C. (2013). Size and performance in family managed firms: surviving first generation. Management Research: Journal of the Iberoamerican Academy of Management, 11(1), 13-34.

2. Csákné F. J., \& Karmazin, G. (2016). Financial Characteristics of Family Businesses and Financial Aspects of Succession. Vezetéstudomány - Budapest Management Review, 47(11), 46- 58.

3. Etemad, H. (2004). Internationalization of small and mediumsized enterprises: A grounded theoretical framework and an overview. Canadian Journal of Administrative Sciences-Revue Canadienne Des Sciences De L Administration, 21(1), 1-21.

4. Etemad, H. (2021). The evolutionary trends of international entrepreneurship in the past two decades: The state of the field in the face of COVID-19's global crisis. Journal of International Entrepreneurship, 19(2), 149-163.

5. Fernandez, Z., \& Nieto, M. J. (2005). Internationalization strategy of small and mediumsized family businesses: Some influential factors. Family Business Review, 18(1), 7789.

6. Ferramosca, S., \& Ghio, A. (2018). Accounting Choices in Family Firms: An Analysis of Influences and Implications. Cham, Switzerland: Springer.

7. Chrisman, J. J., Sharma, P., Steier, L. P., \& Chua, J. H. (2013). The Influence of Family Goals, Governance, and Resources on Firm Outcomes. Entrepreneurship Theory and Practice, 37(6), 1249- 1261.

8. Iwatani, N., Orr, G., \& Salsberg, B. (2021, August). Japan's globalization imperative. McKinsey Quarterly. www.mckinseyquarterly.com. 
9. Kiselakova, D., Soltes, M. \& Soltesova, J. (2015). Theoretical basis of measuring financial efficiency and performance in small and medium-sized enterprises that affect business risks. Exclusive journal: economy and society and environment, 3(3), 182-189.

10. Motylska-Kuzma, A. (2017). The financial decisions of family businesses. Journal of Family Business Management, 7(3), 351- 373.

11. Prasetyo, H. A. (2016). What driver international competitiveness? An empirical test in emerging Indonesian market. Journal of Competitiveness, 8(4), 124-139.

12. Valaskova, K., \& Durana, P. (2020). Global context of disparities in earnings management among enterprises: Evidence from Slovakia. SHS Web of Conferences, 74, Art. No. 01034.

13. Valaskova, K., Durana, P., Adamko, P., \& Jaros, J. (2020). Financial Compass for Slovak Enterprises: Modeling Economic Stability of Agricultural Entities. Journal of Risk and Financial Management, 13(5), Art. No. 92.

14. Węcławski, J. (2017). Dilemmas of family businesses financing by private ekvity. Acta Universitatis Lodziensis. Folia Oeconomica, 1(327), 203-214.

15. Wiener-Fererhofer, A. (2017). Credit rating process: A distinction between family and non-family firms regarding their rating score. Journal of Family Business Management, 7(3), 256-290. 